\title{
LEGIBILITY
}

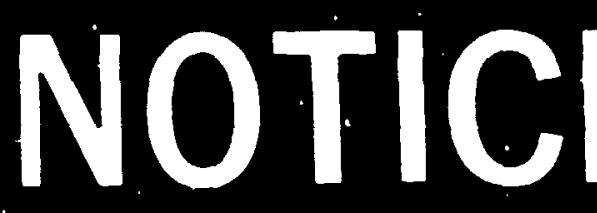

E.

A major purpose of the Technical Information Center is to provide the broadest dissemination possible of information contained in DOE's Research and Developinent Reports to business, industry, the academic community, and federal, state and local governments.

Although a smail portion of this report is not reproducible, it is being made available to expedite the availability of information on the research discussed herein. 


\title{
HEALTH A.VD SAFETY RESEARCH DIVISION
}

Waste Management Research and Development Programs (Activity No. AH 100500 0; NEAH0O1)

\section{RESULTS OF THE RADIOLOGICAL SURVEY AT 1 BRANCA COURT, LODI, NEW JFRSEY (LJ034)}

\author{
R. D. Foley, L. M. Floyd, and R. F. Carrier
}

Date Published - October 1989

Investigation Team

R. E. Swaja - Measurement Applications and Development Manager

W. D. Cottrell - FUSRAP Project Director

R. W. Doane ${ }^{*}$ - Field Survey Supervisor

Survey Team Members
A. C. Butler*
K. S. Dickerson
C. A. Jolinson
B. S. Ellis*
C. A. Muhr
D. W. Greene
E. M. Pilz
W. H. Shinpaughi

W. Winton

* Former Employee of Martin Marietta Energy Systems, Inc. $\nmid$ Stone Associates

Work performed by the MEASUREMENT APPLICATIONS AND DEVELOPMENT GROUP

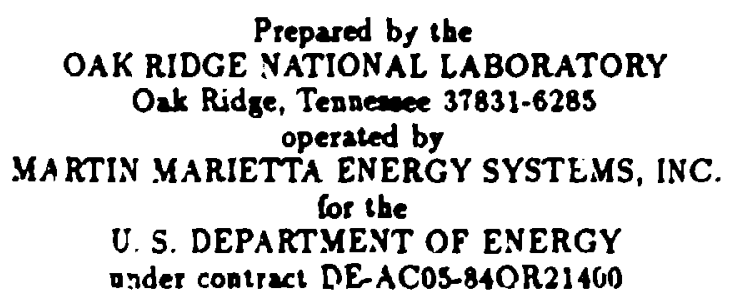




\section{CONTENTS}

LIST OF FIGURES . . . . . . . . . . . . . . . . . . . . v

LIST OF TABLES ........................ vii

ACKNOWLEDGMENTS ................ . . ix

ABSTRACT ...........................

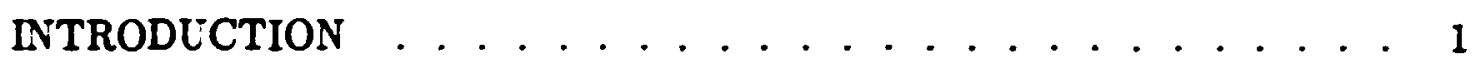

SURVEY METHODS . . . . . . . . . . . . . . 2

SURVEY RESULTS . . . . . . . . . . . . . . . . . . . 2

Surface Gamma Radiation Levels . . . . . . . . . . . . . 3

Systematic and Biased Soil Samples . . . . . . . . . . . . . . 3

Auger Hole Soil Samples and Gamma Logging . . . . . . . . . . 3

SIGNIFICANCE OF FINDINGS . . . . . . . . . . . . . . 3

REFERENCES . . . . . . . . . . . . . . 4 
LIST OF FIGURES

1 Gamma radiation levels $(\mu R / h)$ measured on the surface at 1 Bianca Court, Lodi, New Jersey (LJ034) . . . . . . . . . . . . . 5

2 Diagram showing locations of soil samples taken at 1 Branca Court, Lodi, New Jersey (LJ034) . . . . . . . . . . . . . . . . 6

3 Gamma profile for auger hole 1 (LJ03 \&A1) at 1 Branca Court, Lodi;, New Jersey . . . . . . . . . . . . . . . . . . . 7

4 Gamma profile for auger hole 2 (LJ034A2) at 1 Branca Court, Lodi, New Jersey . . . . . . . . . . . . . . . . . . 8 


\section{LIST OF TABLES}

1 Applicable guidelines for protection against radiation . . . . . . 9

2 Background radiation levels for the northern New Jersey area . . . . . 9

3 Coucentrations of radiomelides in soil at 1 Brance Court, Lcdi, New Jersey (LJ034) . . . . . . . . . . . . . . 10 


\section{ACKNOWLEDGMENTS}

Research for this project was sponsored by the Division of Facility and Site Decommissioning Projects, U.S. Department of Energy, under contract DE-AC55840R21400 with Martin Marictta Energy Systems, Inc. The authors wish to acknowledge the support of J. E Baublitz Acting Director, Office of Remedial Action and Waste Technology, J. J. Fiore. Director, Division of Facility and Site Deconmissioning Projects; and members of their staffs. The authors also appreciate the contributions of $\mathrm{J}$. L Rich, S. W. Hawthorne, and L. J. Jeffers of the Publications Division; i 1 . S. Uziel of the Environmental Remediation Group; I R. Stewart of the Measurement Applications and Development Group; A C. Butler, R. W. Doane, and B. S. Ellis, formet employees or Martin Marietta Energy Systems, Inc; and W. H. Shinfaugh of Don Stone Associates for pa. wetpation in the collection, analyses, editing, and re,porting of data for this survey. 


\begin{abstract}
Maywood Chemical Worts (MCW) of Maywood, New Jersey, generated process wastes and residues associated with the production and refining of thorium and thorium compounds from monazite ores from 1916 to 1956 . MCW supplied rare earth metals and thorium compounds to the Atomic Energy Commission and various other government agencies from the late 1940 s to the mid-1950. Area residents used the sandlike waste from this thoriur. extraction process mived with tea and cocos leaves as mulch in their yards. Some of these contaminated wastes were atso eroded from the site into Lodi Brook At the request of the U.S. Department of Energy (DOE), a group from Oak Ridge National Laboratory conducts investigative radiological surveys of properties in the vicinity of MCW to determine whether a property is contaminated with radioactive residues, principally $32 \mathrm{Th}$, derived from the MCW site. The survey typically includes direct measurement of gamma radiation levels and soil sampling for radionuclide anatyses. The survey of this site, 1 Branca Court, Lodi, New Jersey (LJ034), was conducted during 1985 and 1986.
\end{abstract}

Results of the survey demonstrated no radionuclide concentrations in excess of the DOE Formerly Utilized Sites Remedial Action Program criteria. The radionuclide distributions were not significantly different from normal background levels in the northern New Jersey area. 


\section{RESULTS OF THE RADIOLOGICAL SURVEY AT 1 BRANCA COURT, LODI, NEW JERSEY (LJ034)*}

\section{INTRODUCTION}

From 1916 to 1956, process wastes and residues associated with the production and refining of thorium and thorium compounds from monazite ores were generated by the Maywood Chemical Works (MCW), Maywood, New Jersey. During the latter part of this period, MCW supplied rare earth metals and thorium compounds to various government agencies. In the $1940 \mathrm{~s}$ and $1950 \mathrm{~s}, \mathrm{MCW}$ produced thorium and lithium, under contract, for the Atomic Energy Commission (AEC). These activities ceased in 1956, an: , approximately three years later, the 30-acre real estate was purchased by the Stepan Company. The property is located at 100 Hunter Avenue in a highly developed area in Maywood and Rochelle Park, Bergen County, New Jersey.

During the early years of operation, MCW stored wastes and residues in lowlying areas west of the processing facilities. In the early 1930s, these areas were separated from the rest of the property by the construction of New Jersey State Highway 17. The Stepan property, the interim storage facility, and several vicinity properties have been designated for remedial action by the U.S. Department of Energy (DOE).

The waste produced by the thorium extraction process was a sandlike material containing residual amounts of thorium and its decay products, with smaller quantities of uranium and its decay products. During the years 1928 and 1944 ıo 1946, area residents used these process wastes mixed with tea and cocoa leaves as mulch in their lawns and gardens. In addition, some of the contaminated wastes were apparently eroded from the site into Lodi Brook and carried downstream.

Lodi Brook is a small stream flowing south from Maywood with its headwaters near the Stepan waste storage site. Approximately $150 \mathrm{ft}$ after passing under State Route $1 \bar{i}$, the stream has been diverted underground through concrete or steel culverts until it merges with the Suddle River in Lodi, New Jersey. Coly a small section near Interstate 80 remains uncovered. From the 1940s to the 1970 s when the stream was being diverted underground, its course was altered several times. Some of these changes resulted in the movement of contaminated soil to the surface of a few properties, where it is still in evidence. In other instances, the contaminated soil was covered over or mixed with clean fill, leaving no immediate evidence on the surface. Therefore, properties in question may be drilled in search of former streambed material, even in the absence of surface contamination.

As a result of the Energy and Water Appropriatious Act of Fiscal Year 1984, the property discussed in this report and properties in its vicinity contaminated with residues from the former. MCW were included as a decontamination research

*The survey was performed by members of the Measurement Applications and Development Group of the Health and Safety Research Division at Oal Ridge National Laboratory under DOE contract DE-AC05-84OR21400. 
and development project under the DOE Formerly Utilized Si. ss Remedial Action Program. As part of this project. DOE is conducting radiological surveys in the vicinity of the site to icientify properties contaminated with residues derived from the $\mathrm{MCW}$. The principal radionuclide of concern is thorium-232. The radiological surveys discucjed in this report are par. of that effort and were conducted. it the request of DOE. by members of the Measurement Applications and Development Group of the Oak Ridge National Laboratory.

A radiological survey of the private, residential property at 1 Branca Court, Lodi, New Jersey, was conducted during 1985 and 1986. The survey and sampling of the ground surface were carried out on October 21,1985, and the follow-up subsurface investigation was performed on September 12, 1986.

\section{SURVEY METHODS}

The radiological survey of the property included: (1) a gamma scan of the entire property outdoors, (2) collection of surface and subsurface soil samples, and (3) gamma profiles of auger boles. No indoor survey measurements were performed.

Using a portable gamma scintillation meter, ranges of measurements were recorded for areas of the property surface. If the gamma readings were elevated, a biased soil sample was taken at the point showing the highest gamma radiation level. Systematic soil samples were taken at various locations on the property, irrespective of gamma radiation levels.

To define the extent of possible subsurface soil contarcination, auger holes were drilled to depths of approcimaiely $2.6 \mathrm{~m}$. A plastic pipe was piaced in each hole, and a NaI scintillation probe was lowered inside the pipe. The probe was encased in a lead shield with a horizontal row of collimating slits on the side. This collimation allows measurement of gamma radiation intensities resulting from contamination within small fractions of the hole depth. Measurements were usually made at $15-$ or $30-\mathrm{cm}$ intervals. If the gamma readings in the hole were elevated, a soil saunple was scraped from the wall of the auger hole at the point showing the highest gamma radiation level. The auger hole loggings were used to select locations where further soil sampling would be useful. A split-spoon sampler was used to collect subsurface samples at known depths. In some auger holes, a combination of splitspoon sampling and side-wall scraping was used to collect samples. These survey methods followed the plan outlined in Reference 1. A comprehensive description of the survey methods ard instrumentation has been presented in ancuher report. ${ }^{2}$

\section{SURVEY RESULTS}

Applicable federal guidelines are summarized in Table $1 .^{3}$ The normal background radiation levels for the northe $n$. New Jersey area are presented in Table 2.4 These data are provided for comparison with urvey results presented in this report. All direct measurement results presented in this report are gross readings: background radiation levels have not been subtracted. Similarly. background con- 
centrations have not been subtracted from radionuclide concentrations measured in environmental samples.

\section{Surface Gamma Radiation Levels}

Gamma radiation leveis measured during a gamma scan of the surface of the property are given in Fig. 1. Gamma exposure rates over the major portion of the property rangad from 5 to $9 \mu \mathrm{R} / \mathrm{h}$. The highest gamma levels were from a large rock embedded $0.2 \mathrm{~m}$ below the grass at the southern corner of the house; measurements on the rock were $32 \mu \mathrm{R} / \mathrm{h}$ with the dirt around it ranging from 11 to $13 \mu \mathrm{R} / \mathrm{h}$. Gamma levels on the front steps were 8 to $11 \mu \mathrm{R} / \mathrm{h}$.

\section{Systematic and Biased Soil Samples}

Systematic and biased soil samples were taken from various locations on the property for radionuclide analyses. Locations of the systematic (S) and biased (B) samples are shown in $\mathrm{Fi}_{\circ} \cdot 2$, with results of laboratory analyses provided in Table 3. Concentrations of radium, thorium, and uranium in these samples ranged from 0.63 to $1.0 \mathrm{pCi} / \mathrm{g}, 0.66$ to $1.1 \mathrm{pCi} / \mathrm{g}$, and 0.82 to $1.0 \mathrm{pCi} / \mathrm{g}$, respectively. All samples were near or below normal background levels for the northern New Jersey area (Table 2) and well below DOE guidelines (Table 1).

\section{Auger Hole Soil Sanuples and Gamma Logging}

Varying thicknesses of subsurface sol' were sampled from depths of 105 to $185 \mathrm{~cm}$ in auger holes (A) drilled at two separate locations indicated in Fig. 2. The results of analyses of these samples are given in Table 3 . Concentrations of ${ }^{226} \mathrm{Ra}$ and ${ }^{232} \mathrm{Th}$ in soii samples ranged fror $0.6 \%$, to 0.77 and 0.77 to $1.4 \mathrm{pCi} / \mathrm{g}$, respectively; all values were below DOE crit $\rightarrow$ ria (Table 1) for radium and thorium and near or below background (Table 2).

Gamma logging was performed in each of the auger holes to characterize and further define the extent of possible contamination. The logging technique used here is not radionuclide specific. However, logging data, in conjunction with soil analyses data, may be used to estimate regions of elevated radionuclide concentrations in auger holes when compared with background levels for the area. Following a comparison of these data, it appears that any shieided scintillator readings of 1000 counts per minute (cpm) or greater generally indicate the presence of ele. vated concentrations of ${ }^{226} \mathrm{Ra}$ and ior ${ }^{232} \mathrm{Th}$. Data from the gamma profiles of the logged auger holes are graphically represented in Figs. 3 and 4. All readings were near or below $1000 \mathrm{cpm}$.

\section{SIGNIFICANCE OF FINDINGS}

Measurements and results of soil sample analyses taken at 1 Branca Court indicate that the property contained no radionuclide concentrations above DOE guideline values. The radionuclide distributions on this property were similar to normal background leveis for the northern New Jersey area. 


\section{REFERENCES}

1. W. D. Cottrell, ORNL, to A. J. Whitman, DOE/HQ, correspondence, "Radiological Survey of Private Properties in Lodi, New Jersey" (August 15, 1984).

2. T. E. Myrick, B. A. Berven, W. D. Cottrell, W. A. Goldsmith, and F. F. Haywood, Procedures Manual for the ORNL Radiological Survey Activities (RASA) Program, Oak Ridge National Laboratory, ORNL/TM-\$600 (April 1987).

3. U.S. Department of Energy, Guidelines for Residual Radioactive Material at Formerly Utilized Sites Remedial Action Program and Remote Surplus Facilities Management Program Sites (Rev. 2, March 1987).

4. T. E. Myrick, B. A. Berven, and F. F. Haywood, State Background Radiation Levels: Results of Measurements Taken During 19751979,Oak Ridge National Laboratory, ORNL/TM-7343 (November 1981). 
ORNL-OWG 89-10788

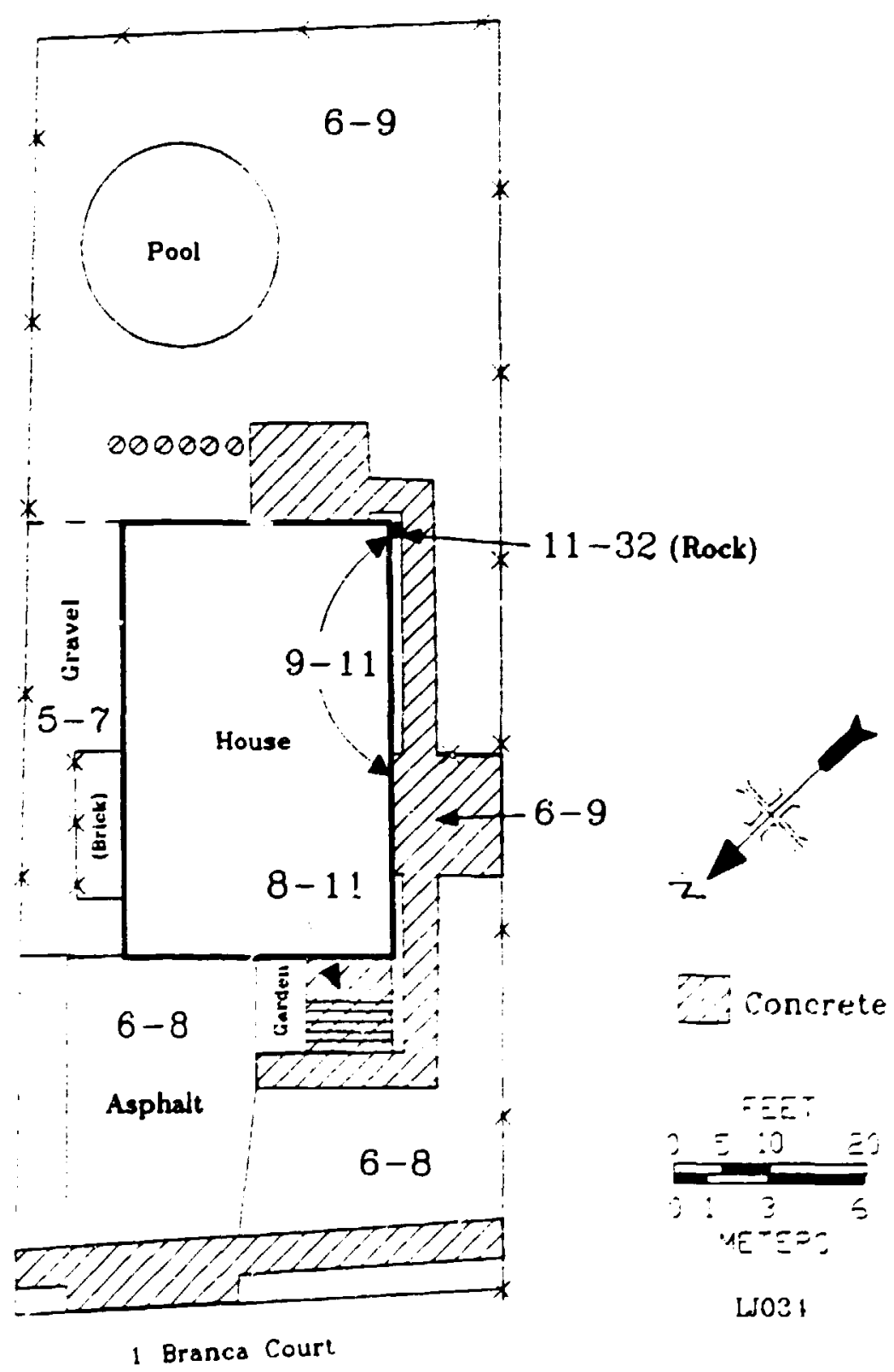

Fig. 1. Gamma radiation levels $(\mu R / h)$ measured on the surface at 1 Branca Court, Lodi, New Jersey (LJ034). 
ORNL-DWG 89-10789

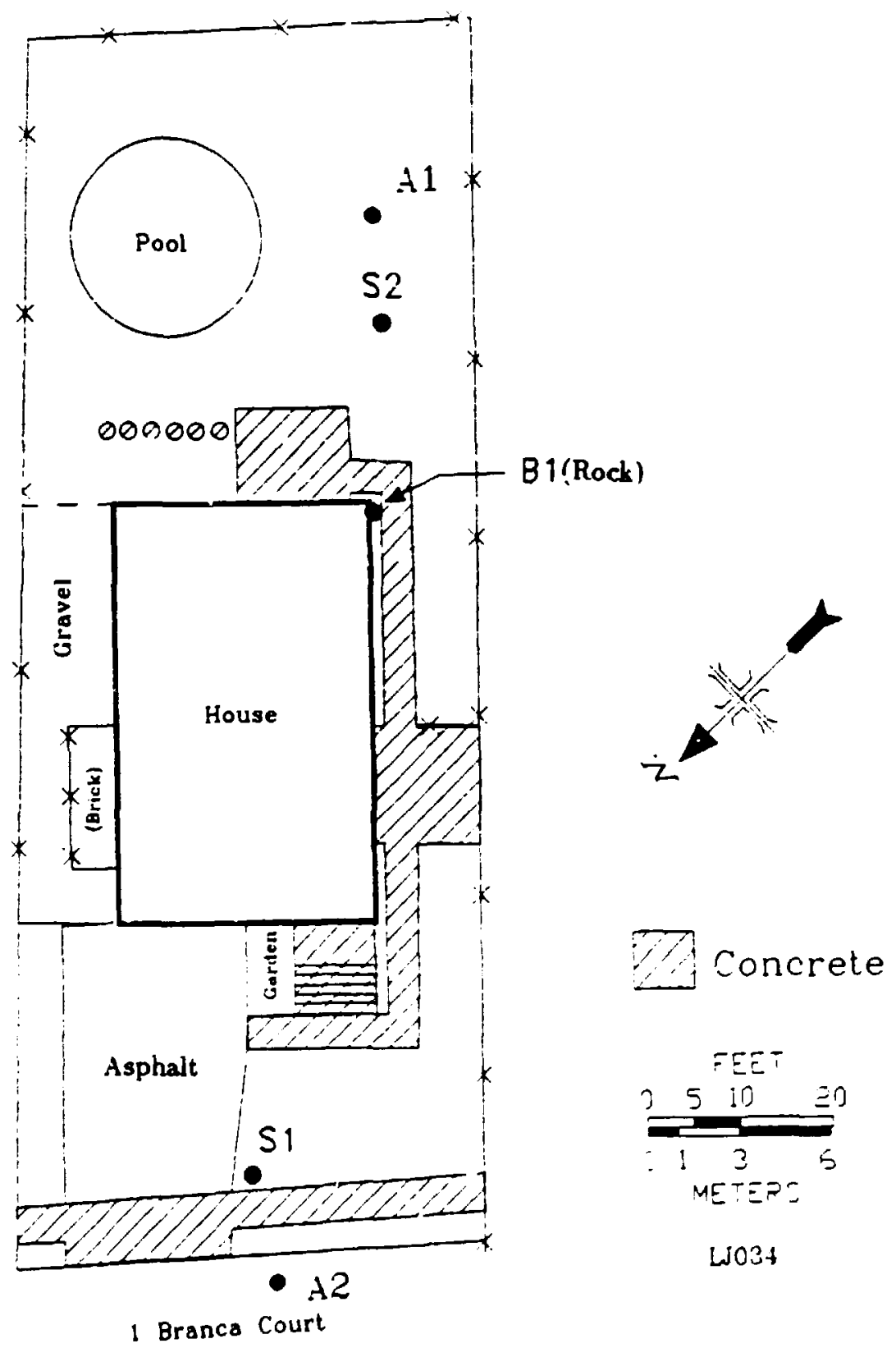

Fig. 2. Diagram showing locations of soil samples taken at 1 Branca Court, Lodi, New Jersey (LJC34). 
ACTVITY (1000 CPM)

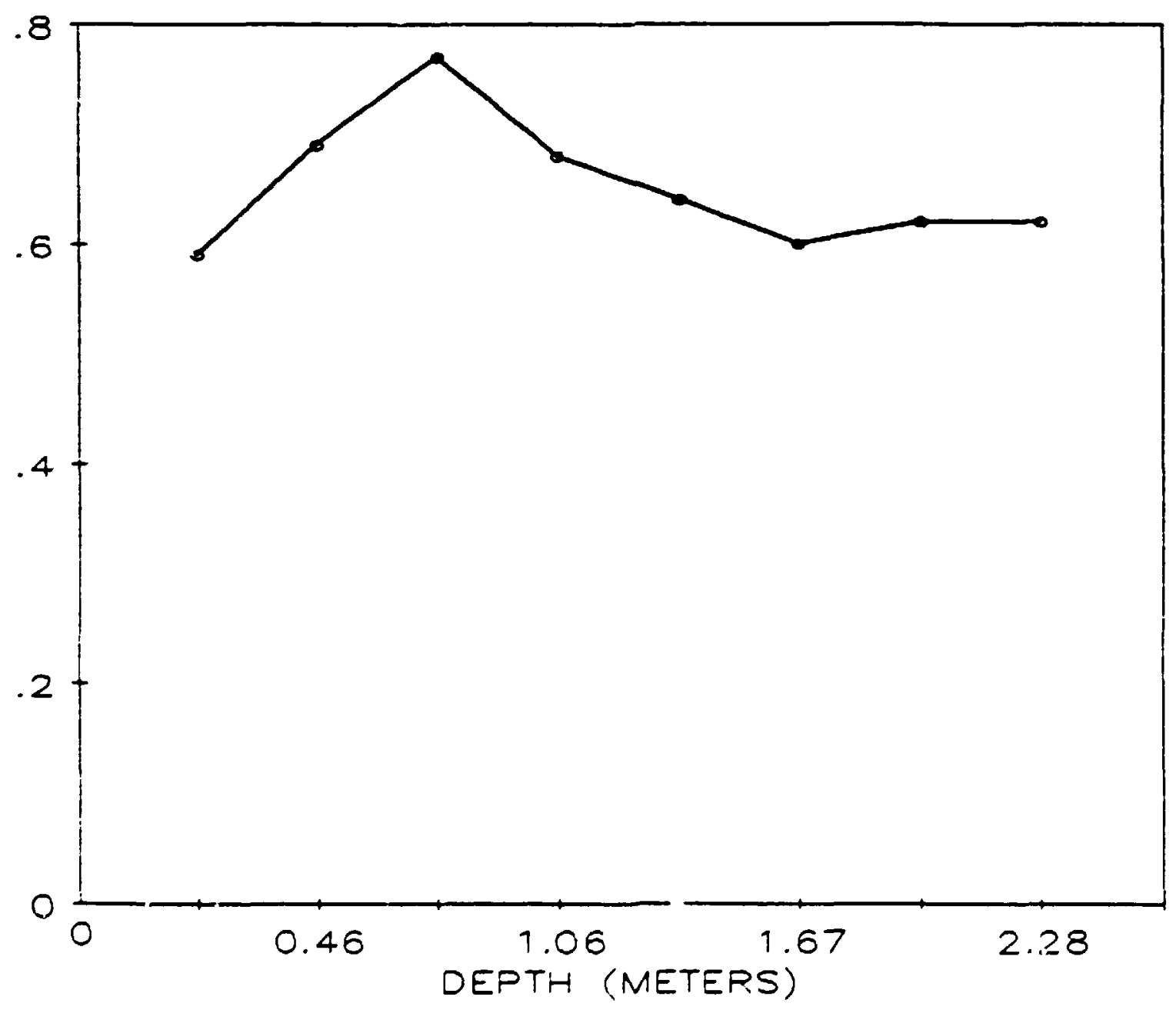

Fig. 3. Gamma profile for auger hole 1 (LJ034A1) at 1 Branca Court, Lodi, New Jersey. 
ACTIVITY (1000 CPM)

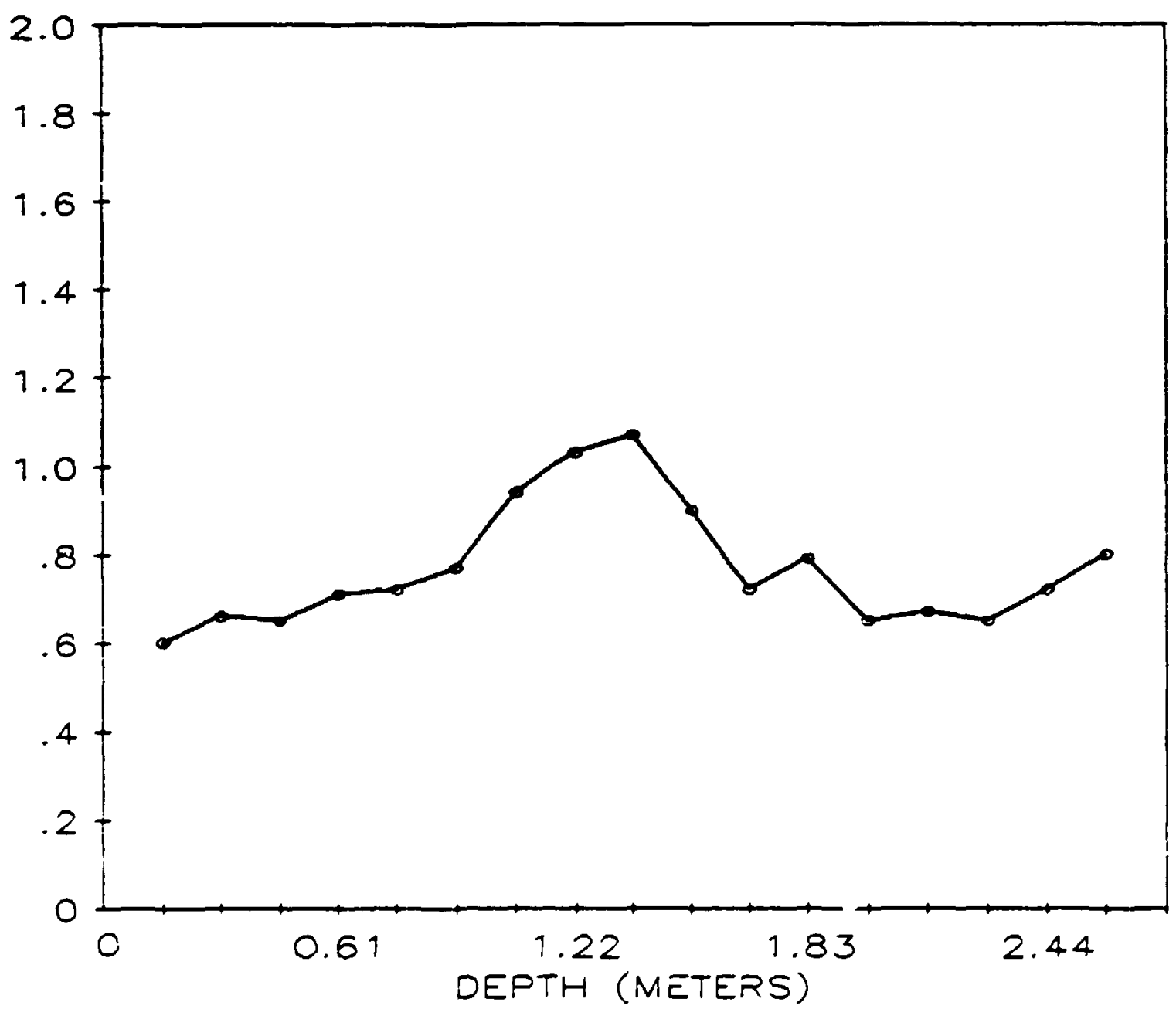

Fig. 4. Gamma profle for auger hole 2 (LJn34A2) at 1 Branca Court, Lodi, New Jersey. 
Table 1. Applicable guidelines for protection against radiation

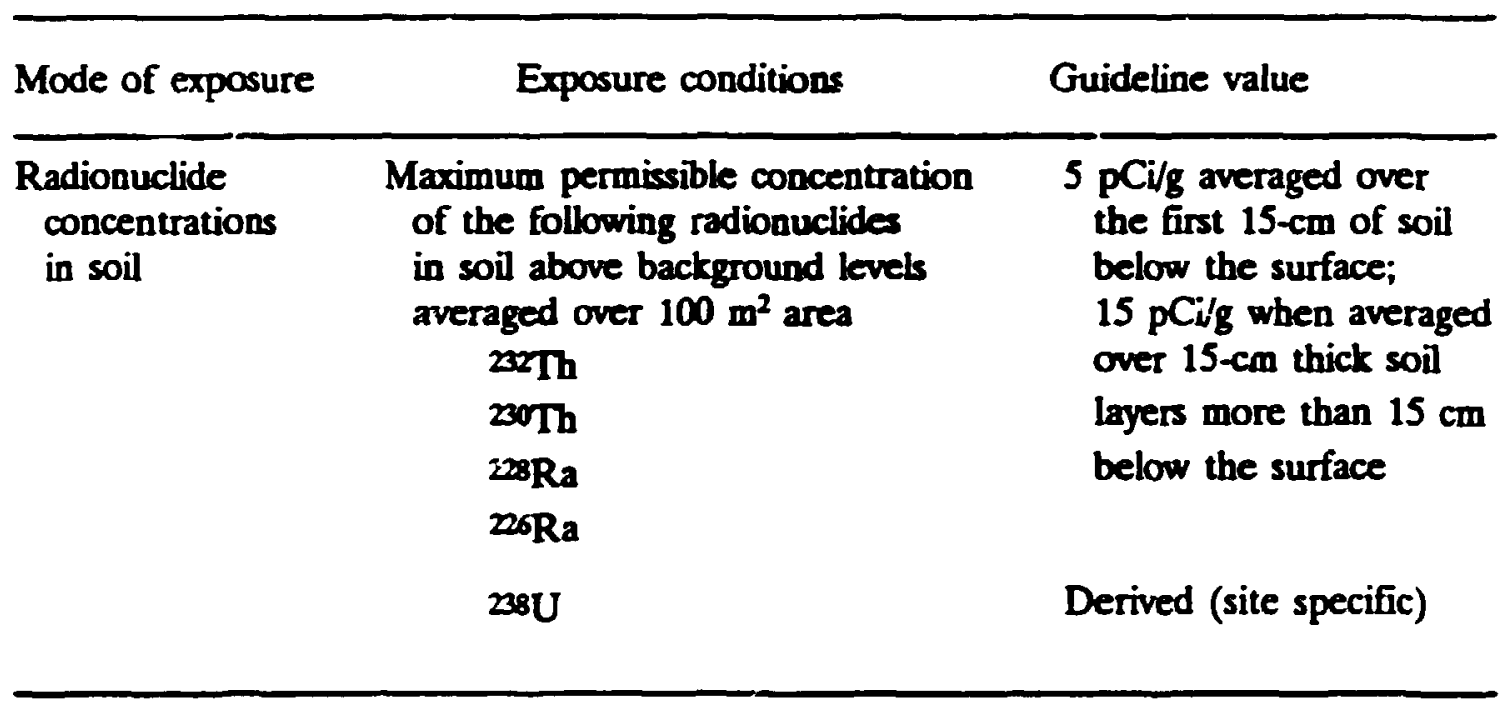

'Reference 3.

Table 2 Background radiation levels for the northern New Jersey area

\begin{tabular}{cc}
\hline $\begin{array}{c}\text { Type of radiation measurement } \\
\text { or sample }\end{array}$ & $\begin{array}{c}\text { Radiation level or } \\
\text { radionuclide concentration }\end{array}$ \\
\hline $\begin{array}{c}\text { Concentration of radionuclides } \\
\text { in soil }(\mathrm{pCi} / \mathrm{g})\end{array}$ & \\
& \\
$226 \mathrm{Ra}$ & 0.9 \\
$232 \mathrm{Th}$ & 0.9 \\
$23 \mathrm{U}$ & 0.9
\end{tabular}

'Reference 4. 
Table 3. Concentrations of radionuclides in soil at 1 Branca Court, Lodi, New Jersey (LJ034)

\begin{tabular}{|c|c|c|c|c|}
\hline \multirow{2}{*}{ Sample: } & \multirow{2}{*}{$\begin{array}{c}\text { Depth } \\
(c, n)\end{array}$} & \multicolumn{3}{|c|}{ Radionuclide concentration (pCi/g) } \\
\hline & & ${ }^{206} \mathbf{R a}$ & ${ }^{232} \mathrm{Th}^{6}$ & ${ }^{238} U^{c}$ \\
\hline \multicolumn{5}{|c|}{ Systematic samplesd } \\
\hline $\begin{array}{l}\mathbf{S 1} \\
\mathbf{S 2}\end{array}$ & $\begin{array}{l}0-15 \\
0-15\end{array}$ & $\begin{array}{l}0.63 \div 0.09 \\
0.75 \div 0.1\end{array}$ & $\begin{array}{l}0.67 \pm 0.07 \\
0.66 \times 0.5\end{array}$ & $\begin{array}{l}1.0 \\
0.82\end{array}$ \\
\hline \multicolumn{5}{|c|}{ Biased samplese } \\
\hline $\begin{array}{l}\mathbf{B} 1 \mathbf{A} \\
\mathbf{B} 1 \mathbf{B}\end{array}$ & $\begin{array}{r}0-15 \\
15-30\end{array}$ & $\begin{array}{r}1.0 \times 0.2 \\
0.88 \times 0.2\end{array}$ & $\begin{array}{r}0.95,0.8 \\
1.1 \times 0.8\end{array}$ & $\begin{array}{l}0.99 \\
0.90\end{array}$ \\
\hline \multicolumn{5}{|c|}{ Auger samplest } \\
\hline $\begin{array}{l}\text { A1A } \\
\text { A1B } \\
\text { A2A }\end{array}$ & $\begin{array}{l}120-150 \\
150-185 \\
105-135\end{array}$ & $\begin{array}{l}0.74 \times 0.02 \\
0.60 \div 0.03 \\
0.77 \times 006\end{array}$ & $\begin{array}{l}0.79 \pm 0.07 \\
0.77 \pm 0.1 \\
1.4 \div 0.1\end{array}$ & 8 \\
\hline
\end{tabular}

'Locations of soil samples are shown on Fig. 2

'Indicated counting error is at the $95 \%$ confidence level $( \pm 20)$.

Total analytical error of measurement results is less than $5 \%(95 \%$ confidence level).

JSystemai:i samples are taken at locations irrespective of gamma exposure rates.

'Biased samples are taken from areas shown to have elevated gamma exposure rates.

'Auger samples are taken from holes drilled to further define the depth and extent of radioactive material. Holes are drilled where the surface may or may not be contaminated.

Sample was not analyzed for 2 U. 